\title{
STRATEGI PENINGKATAN PERAN MASYARAKAT DALAM MELESTARIKAN EKOWISATA MANGROVE DAN BEKANTAN DI KELURAHAN KARANG REJO TARAKAN BARAT
}

\author{
Muhammad Arbain ${ }^{1}$, Nurul Chairiyah ${ }^{2}$ \\ ${ }^{1}$ Jurusan Agribisnis, Fakultas Pertanian, Universitas Borneo Tarakan \\ ${ }^{2}$ Jurusan Agroteknologi, Fakultas Pertanian, Universitas Borneo Tarakan \\ Email : m.asnawi.arbain@gmail.com
}

Diterima: 12 Maret 2020

Disetujui: 3 April 2020

\begin{abstract}
Mangrove ecosystems have an important role in sustainable development both ecologically, economically and socially. Today, mangrove forests as ecotourism are much in demand by local and foreign communities as a nature tourism trip with the aim of enjoying and studying the natural ecosystems and socio-cultural local communities. This study aims to find out and formulate strategies to increase the role of the community in preserving mangrove and bekantan ecotourism in Karang Rejo village, West Tarakan. The method used is descriptive qualitative data collection techniques in the form of observation, interviews, and documentation. The data analysis used is the SWOT analysis (Strength, Weakness, Opportunity, and Threats). The results of the study found strategies to increase the role of the community in preserving local wisdom of mangrove ecotourism that can be used are: (1) Revitalizing infrastructure facilities of mangrove and bekantan ecotourism to be more productive and attractive; (2) Providing soft skills training to the community regarding the use of mangrove forests; (3) Promoting mangrove and bekantan ecotourism through social and elektronic media; (4) Cooperating with all stakeholders in supporting the preservation of mangrove forests, and; (5) Developing local handicraft products industry with make some souvenir, food, and medicines from mangrove raw materials.
\end{abstract}

Keyword: Strategy, Community Role, Ecotourism, Mangroves and Bekantan

\begin{abstract}
ABSTRAK
Ekosistem mangrove mempunyai peranan penting dalam pembangunan berkelanjutan baik secara ekologis, ekonomis, maupun sosial. Hutan mangrove sebagai ekowisata dewasa ini banyak diminati oleh masyarakat lokal maupun mancanegara sebagai sebuah perjalanan wisata alam dengan tujuan menikmati dan mempelajari ekosistem alam dan sosial budaya masyarakat lokal. Penelitian ini bertujuan untuk mengetahui dan merumuskan strategi peningkatan peran masyarakat dalam melestarikan ekowisata mangrove dan bekantan di kelurahan Karang Rejo Tarakan Barat. Metode yang digunakan adalah deskriptif kualitatif dengan teknik pengumpulan data berupa observasi, wawancara, dan dokumentasi. Adapun analisis data yang digunakan adalah analisis SWOT (Strenght,Weakness, Opportunity, dan Threats). Hasil penelitian ditemukan strategi peningkatan peran masyarakat dalam melestarikan kearifan lokal ekowisata mangrove yang dapat dilakukan adalah: (1) Revitalisasi Sarana Prasarana (Sanpras) ekowisata mangrove dan bekantan agar lebih produktif dan menarik; (2) Melakukan pelatihan soft skill kepada masyarakat tentang pemanfaatan hutan mangrove; (3) Melakukan promosi ekowisata mangrove dan bekantan melalui media cetak maupun media elektronik; (4) Melakukan kerjasama dengan seluruh stakeholder dalam mendukung pelestarian hutan mangrove, dan; (5) Mengembangkan industri produk kerajinan lokal masyarakat seperti sovenir, makanan, dan obat-obatan dari bahan baku mangrove.
\end{abstract}

Kata kunci: Strategi, Peran Masyarakat, Ekowisata, Mangrove dan Bekantan

\section{PENDAHULUAN}

Ekosistem mangrove mempunyai
peranan penting dalam pembangunan
berkelanjutan baik secara ekologis, ekonomis,
maupun sosial. Pengelolaan ekosistem yang
berkelanjutan dapat dicapai jika
mempertimbangkan seluruh aspek, baik aspek

fisik maupun non fisik. Banyaknya stakeholders yang berkepentingan terhadap ekosistem mangrove berpotensi sebagai sumber konflik yang menyebabkan pengelolaan ekosistem mangrove yang berkelanjutan menjadi tidak efektif dan sering kali mengalami kegagalan. Kegagalan pengelolaan mangrove diindikasi karena minimnya pelibatan masyarakat dan 
kebijakan manajemen yang bersifat top down. Sebagai pihak yang bersentuhan langsung dengan ekosistem mangrove, masyarakat sekitar perlu dilibatkan dalam pengelolaannya. Pemerintah perlu memberi kesempatan kepada masyarakat sekitar kawasan untuk turut berperan dalam upaya pengelolaan mangrove dan pengawasanya, juga untuk meminimalisir konflik yang menjadi penghambat dalam pengelolaan mangrove. Maka dari itu, diperlukan peran serta masyarakat dalam memperhatikan persepsi dan nilai mangrove bagi masyarakat.

Pengelolaan hutan mangrove tidak lepas dari pelibatan peran masyarakat. Tidak bisa dipungkiri, terdapat masyarakat yang bergantung pada keberadaan mangrove untuk memenuhi kebutuhan hidupnya. Masyarakat yang hidup di sekitar mangrove memanfaatkan ikan, udang, kepiting, dan kayu bakar yang tersedia. Belum lagi keberadaan mangrove dan bekantan menjadi peluang usaha bagi masyarakat sekitar untuk berdagang berbagai jenis makanan, cemilan, dan minuman, bahkan souvenir khas mangrove dan bekantan (Dhimas, 2011).

Masyarakat kelurahan Karang rejo Tarakan Barat Kota Tarakan merupakan objek yang bersentuhan langsung dengan keberadaan mangrove dan bekantan. Maka dari itu, pemerintah perlu melibatkan masyarakat dalam pengelolaan dan pelestarian mangrove dan bekantan agar tercipta hubungan yang harmonis antara masyarakat dan pemerintah dalam mendukung pembangunan berkelanjutan di bidang ekowisata alam. Hal ini sebagaimana yang tertuang dalam Undang-Undang Republik Indonesia Nomor 41 Tahun 1999 tentang kehutanan bahwa mangrove merupakan suatu ekosistem hutan, maka pemerintah bertanggung jawab untuk mengelola mangrove berdasarkan asas manfaat dan lestari, kerakyatan, keadilan, kebersamaan, keterbukaan, dan keterpaduan. Kebijakan yang diambil oleh pemerintah daerah dalam pengelolaan mangrove akan memengaruhi kelestarian dan keberadaan hutan mangrove menjadi pengembangan ekowisata.

Pengembangan ekowisata selanjutnya diatur dalam Peraturan Menteri Dalam Negeri Nomor 33 Tahun 2009 bahwa prinsip pengembangan ekowisata meliputi: (1) kesesuaian antara jenis dan karakteristik ekowisata; (2) konservasi, yaitu melindungi, mengawetkan, dan memanfaatkan secara lestari sumber daya alam yang digunakan ekowisata;
(3) ekonomis, yaitu memberikan manfaat untuk masyarakat setempat dan menjadi penggerak pembangunan ekonomi di wilayahnya serta memastikan usaha ekowisata dapat berkelanjutan; (4) edukasi, yaitu mengandung unsur pendidikan untuk mengubah persepsi seseorang agar memiliki kepedulian, tanggungjawab, dan komitmen terhadap pelestarian lingkungan dan budaya; (5) memberikan kepuasan dan pengalaman kepada pengunjung; (6) partisipasi masyarakat, yaitu peran serta masyarakat dalam kegiatan perencanaan, pemanfaatan, dan pengendalian ekowisata dengan menghormati nilai-nilai sosial-budaya dan keagamaan masyarakat di sekitar kawasan; dan (7) menampung kearifan lokal.

Berdasarkan pada landasan hukum di atas, maka terbitlah Peraturan Daerah Nomor 4 Tahun 2002 Tentang Pengawasan Hutan Mangrove di Kota Tarakan sebagai wujud membangun kearifan lokal masyarakat setempat dalam melindungi, memelihara, dan melastarikan hutan mangrove. Peraturan daerah mengenai perlindungan kawasan hutan mangrove ini merupakan hal yang penting sebagai pengontrol kegiatan masyarakat di kawasan tersebut dalam mengatur pengelolaan sumber daya alam dan lingkungan. Pelestarian hutan mangrove tidak hanya tugas pemerintah saja, tetapi harus bersinergi dengan masyarakat setempat

Strategi peningkatan peran masyarakat dalam melestarikan ekowisata mangrove telah dilakukan oleh Muriyanto dan Lalu Masyhudi (2018) yang meneliti tentang strategi pengembangan ekowisata berbasis masyarakat lokal di Teluk Seriwe Lombok Timur. Bekti Utomo, dkk (2017) juga meneliti tentang strategi pengelolaan mangrove di Desa Tanggul Tlare. Kemudian Tamrin Salim, dkk (2018) juga melakukan penelitian mengenai strategi pengembangan ekowisata mangrove TongkeTongke di Kabupaten Sinjai. Namun, strategi peningkatan peran masyarakat dalam melestarikan ekowisata mangrove belum banyak dikaji. Oleh karena itu, peneliti tertarik untuk melakukan penelitian dengan judul Strategi Peningkatan Peran Masyarakat dalam Melestarikan Ekowisata Mangrove dan Bekantan di Kelurahan Karang Rejo Tarakan Barat. Tujuan dari penelitian ini adalah untuk mengetahui dan merumuskan strategi peningkatan peran masyarakat dalam 
melestarikan ekowisata mangrove dan bekantan di kelurahan Karang Rejo Tarakan Barat.

\section{METODE}

\section{A.Waktu dan Tempat}

Penelitian dilaksanakan di Kelurahan Karang Rejo Kota Tarakan Provinsi Kalimantan Utara tepatnya di Kawasan Konservasi Mangrove dan Bekantan (KKMB). Waktu penelitian direncanakan selama 3 bulan, dimulai pada bulan Agustus sampai dengan November 2019.

\section{B.Teknik Pengambilan Data}

Populasi dalam penelitian ini adalah masyarakat yang berada di sekitar ekowisata mangrove. Untuk memperoleh sampel yang benar-benar representatif dengan kesempatan yang sama bagi seluruh populasi yang menjadi sampel, maka teknik sampling yang digunakan teknik sampling tertuju (purposing sampel) yang meliputi pihak pemerintah, pedagang dan masyarakat sekitar ekowisata. Teknik ini juga sebagai sampling pertimbangan (Nasution ,2002), karena pengambilan sampel dilakukan berdasarkan pertimbangan perorangan atau pertimbangan peneliti. Penggunaan teknik sempling ini dengan tujuan agar semua lapisan masyarakat mempunyai kesempatan yang sama untuk dipilih sebagai sampel

\section{C.Teknik Analisis Data}

Analisis data yang digunakan untuk menjawab tujuan pertama yaitu mengetahui peran masyarakat dalam melestarikan kearifan lokal ekowisata hutan mangrove di Kota Tarakan dengan analisis deskriptif kualitatif. Sugiyono (2011) mengartikan penelitian deskriptif kualitatif sebagai prosedur pemecahan masalah dengan menuliskan, menjabarkan, menggambarkan atau melukiskan keadaan subjek atau objek penelitian (seseorang, lembaga, masyarakat, dan lain-lain) pada saat sekarang berdasarkan fakta-fakta yang tampak sebagaimana mestinya.

Merumuskan strategi peningkatan peran masyarakat dalam pelestarian kearifan lokal ekowisata hutan mangrove di Kota Tarakan menggunakan analisis SWOT. Konsep analisis SWOT menurut Sugiyanto et al (2009), langkah awal dilakukan Analisa Lingkungan Internal (ALI) maupun Analisa Lingkungan Eksternal (ALE) dengan pendekatan analisis SWOT (Strengths, Weaknesses, Opportunities, Threats). Analisa Lingkungan Internal (ALI) terdiri atas Kekuatan (Strengths) dan Kelemahan
(Weaknesses), sedangkan Analisa Lingkungan Eksternal (ALE) terdiri atas Peluang (Opportunities) dan Ancaman (Threats).

Berdasarkan analisis SWOT tersebut selanjutnya ditentukan bobot matrik urgensi. Selanjutnya dapat diketahui posisi strateginya. Langkah selanjutnya dari Analisis SWOT adalah menetapkan tindakan strategis ke dalam 4 (empat) kategori, dengan memperhatikan hasil penentuan posisi strategi di atas. Adapun tindakan strategis tersebut adalah sebagai berikut: (1) Strategi SO yaitu memaksimalkan kekuatan untuk memanfaatkan peluang; (2) Strategi ST yaitu memaksimalkan kekuatan untuk mengurangi ancaman; (3) Strategi WO yaitu meminimalkan kelemahan untuk memanfaatkan peluang; (4) Strategi WT meminimalkan kelemahan untuk mengurangi ancaman.

\section{HASIL DAN PEMBAHASAN}

\section{Gambaran Umum Ekowisata Hutan Mangrove dan Bekantan Kelurahan Karang Rejo}

Ekowisata hutan mangrove kota Tarakan berada di wilayah kelurahan Karang Rejo, Tarakan Barat. Kelurahan Karang Rejo memiliki luas wilayah daratan $0,76 \mathrm{~km} 2$, dengan jumlah penduduk 8.964 jiwa. (Badan Pusat Statistik Kota Tarakan, 2018). Masyarakat yang mendiami wilayah kelurahan Karang Rejo ini beranekaragam etnis, agama, dan budaya.

Kawasan hutan di Kota Tarakan ditetapkan berdasarkan pemanfaatannya, secara ekologis dan biologis terbagi ke dalam hutan lindung dan hutan konservasi dengan tujuan khusus sebagai hutan kota dan hutan mangrove (Badan Pengelolaan Lingkungan Hidup, 2010). Hutan mangrove merupakan bagian ekosistem pesisir Kota Tarakan yang menyediakan sumberdaya alam produktif, baik sebagai sumber pangan, tambang mineral dan energi seperti minyak dan gas serta batu bara, media komunikasi maupun kawasan rekreasi atau pariwisata (Pratiwi, 2013). Peranan hutan mangrove dalam kehidupan ditunjukkan oleh fungsi mangrove terkait aspek sosio-ekologis, sosio-ekonomis, dan sosio-kultural. Fungsi ekologis hutan mangrove yang paling menonjol adalah sebagai pelindung garis pantai dan kehidupan di belakangnya dari gempuran tsunami dan angin, mencegah terjadinya salinasi pada wilayah-wilayah di belakangnya, dan sebagai habitat bagi biota perairan. Secara 
ekonomis, pemanfaatan hutan mangrove berasal dari hasil kayunya sebagai kayu bangunan, kayu bakar dan bahan kertas serta hasil hutan bukan kayu, selain juga difungsikan sebagai kawasan wisata alam pantai. Secara sosial, hutan mangrove juga berfungsi melestarikan keterkaitan hubungan sosial dengan masyarakat lokal, sebagai tempat mencari ikan, kepiting, udang, dan bahan obat-obatan (Dahuri et al., 2001).

Hutan mangrove kota Tarakan merupakan hutan mangrove yang sedari awal sudah ada dan dikelola oleh masyarakat pada tahun 2000 melalui swadaya masyarakat, karena hutan mangrove ini merupakan lahan mata pencaharian masyarakat setempat untuk menangkap ikan, udang, dan kepiting yang dahulunya merupakan kawasan tambak yang memiliki luas 9 (sembilan) hektar. Pengelolaan hutan mangrove yang berkelanjutan dirasakan sangat penting oleh Pemerintah Kota Tarakan, sehingga pada tahun 2001 ditetapkan Kawasan Konservasi Mangrove Bekantan (KKMB) seluas sembilan hektar dengan tujuan untuk melindungi ekosistem mangrove termasuk didalamnya satwa endemik Kalimantan yaitu bekantan (Nasalis larvatus Wurmb, 1787) (Save Our Environment, 2012). Penetapan KKMB diikuti dengan pembangunan fasilitas pada tahun 2003 berupa jembatan, menara pengamatan, gazebo, perpustakaan, dan karantina untuk pemeriksaan satwa. Pada tahun 2006, KKMB diperluas menjadi 22 hektar atas kesepakatan dan dukungan Pemerintah Kota Tarakan dan DPRD Kota Tarakan. Selain itu, World Wildlife Fund (WWF) sebagai mitra, memberikan dukungan serta berperan aktif dalam penelitian dan kelestarian mangrove di Kota Tarakan, tertuang bentuk Nota Kesepahaman (MoU) antara Pemerintah Kota Tarakan, WWF, dan PT Minanusa Aurora untuk merehabilitasi kawasan ini. Selanjutnya, pada tahun 2007 kawasan ini direhabilitasi dengan penanaman tumbuhan mangrove melalui kemitraan bersama antara PT Minanusa Aurora dan Nichirei Fresh Ltd, Ganko Food Industries, Provident Indonesia Energy, PT Medco, dan PT PLN (Badan Pengelolaan Lingkungan Hidup, 2010). Kawasan Konservasi Mangrove Bekantan yang ditujukan untuk melestarikan ekosistem mangrove dan satwaliar dalam perkembangannya diarahkan sebagai daerah tujuan ekowisata alternatif (Dinas Lingkungan Hidup dan SDA Kota Tarakan, 2007; Yusuf, 2008). Ekowisata memberikan kesempatan bagi para wisatawan untuk menikmati keindahan alam dan budaya lokal serta mempelajari tentang pentingnya berbagai ragam mahluk hidup yang ada di dalamnya. Selain itu, kegiatan ekowisata juga dapat meningkatkan pendapatan untuk pelestarian alam serta menghasilkan keuntungan ekonomi bagi kehidupan masyarakat di sekitarnya (Subadra, 2008). Bahkan tidak hanya itu, Hutan Mangrove ini selain menjadi objek wisata juga menjadi paruparu Kota Tarakan serta sebagai pelindung dari abrasi air laut, mengingat Kota Tarakan merupakan pulau kecil yang di kelilingi laut.

Hutan mangrove kota Tarakan dijadikan sebuah kawasan hutan konservasi sekaligus ekowisata merupakan asset pariwisata yang memiliki nilai ekologis dan ekonomis yang banyak menghipnotis para wisatawan baik dari mancanegara, domestik, maupun lokal. Hutan mangrove Tarakan selain menjadi konservasi alam, namun juga sebagai salah satu konservasi keberadaan bekantan. Bekantan adalah jenis kera langka endemik khas Pulau Kalimantan yang sangat dilindungi. Ada sekitar empat puluh (40) kera bekantan yang merupakan ikon yang memiliki nilai daya tarik tersendiri bagi para pengunjung. Hutan mangrove Tarakan juga menjadi habitat alami pohon-pohon bakau dan juga fauna khas Tarakan. Kekayaan faunanya menjadikan hutan mangrove ini sebagai laboratorium hidup oleh para peneliti baik dari dalam maupun luar negeri. Di dalamnya tidak hanya ada berbagai macam jenis tumbuhan mangrove, tetapi juga banyaknya biota laut seperti ikan, kepiting, burung, dan berbagai jenis biota laut dan fauna lainnya.

Kawasan Konservasi Hutan Mangrove dan Bekantan (KKMB) Kota Tarakan, Kalimantan Utara ini mengalami perluasan dan rehabilitasi yang berkali-kali, dari 9 hektar, 12 hektar, hingga sekarang sudah terjadi perluasan sebanyak 22 hektar. Masyarakat yang berada di sekitar kawasan adalah masyarakat Karang Rejo Kecamatan Tarakan Barat. Untuk mendukung lestarinya hutan mangrove sebagai kawasan konservasi dan bekantan sekaligus sebagai ekowisata, maka peran masyarakat sekitar sangat penting dalam hal pengelolaan, pengawasan dan pelestarian.

Peran Pemerintah, Pedagang, dan Masyarakat

1.Kementerian Kelautan dan Perikanan(KKP) Kementerian Kelautan dan Perikanan (KKP) Kota Tarakan memiliki fungsi dan peran strategis dalam melakukan pengelolaan dan 
pengawasan ekowisata hutan mangrove. Pemerintah daerah dalam hal ini Kementerian Kelautan dan Perikanan (KKP) telah melakukan berbagai upaya dalam mengelola kawasan konservasi hutan mangrove dan bekantan (KKMB) sebagai ekowisata dengan melengkapi berbagai sarana prasarana didalamnya seperti membuat boardwalk berupa jembatan kayu yang memutari pohon-pohon mangrove tanpa memotong pohon-pohon mangrove tersebut (alami) dengan panjang 2.400 meter dan lebar 2 meter, membangun beberapa pusat kegiatan masyarakat seperti gazebo berjualan makanan dan sovenir, rumah karantina bekantan, mushalla, perpustakaan, toilet, dan berbagai petunjuk arah yang dapat memudahkan pengunjung dalam beraktivitas di dalam konservasi hutan mangrove dan bekantan. Namun, akibat tidak adanya pengelolaan secara berkelanjutan dan kurang terawatnya fasilitas ini menyebabkan kepuasan pengunjung semakin berkurang bahkan sepi peminat. Kondisi ini juga diperburuk dengan banyaknya sampah an-rganik yang terdapat di lokasi akibat terbawa oleh air pasang surut (Taqwa, 2010).

Tidak hanya itu, pemerintah juga menamakan berbagai jenis pohon mangrove dan mengedukasi berbagai fauna yang ada di dalam hutan mangrove dan bekantan seperti jenis burung, ikan, dan kepiting. berdasarkan hasil penelitian Dhimas Wiharyanto (2011) terdapat 3 famili dan 4 jenis yang mayoritas didominasi oleh famili Sonneratiaceae Alba (Prapat), Avicenniaceae Alba (Api-Api), Avicennia Marina, Nypa Futicans. Sedangkan berdasarkan hasil penelitian Dhimas Wiharyanto (2007) ditemukan 6 Famili dan 13 spesies pohon mangrove. Adapun hasil penemuan yang dilakukan oleh Rugian (2003), terdapat 5 famili dan 9 spesies pohon mangrove. Sementara hasil penelitian yang dilakukan Reny, dkk (2013) dari Pusat Litbang Konservasi dan Rehabilitasi ditemukan 5 (lima) jenis mangrove yaitu Avicennia sp, Bruguiera sp, Bruguiera parviflora (Roxb) Wright \& Arn ex Griff, Ceriops tagal (Perr) C.B.Rob, Rhizophora apiculata Blume, Rhizophora stylosa Griff. Perbedaan jumlah jenis yang diperoleh diduga karena kawasan penelitian ini dahulunya merupakan kawasan bekas tambak yang dijadikan lahan konservasi. Kemudian kawasan ini mengalami perbaikan oleh alam dan rehabilitasi yang dilakukan oleh Pemerintah Kota Tarakan pada tahun 2007 dengan pembibitan dan penanaman kembali kawasan ekosistem hutan mangrove dan bekantan (KKMB).

Kondisi satwa liar yang ada di kawasan konservasi dan bekantan (KKMB) ditemukan beberapa jenis satwa liar yang termasuk ke dalam kelas mamalia yaitu bekantan (Nasalis larvatus Wurmb, 1787), monyet ekor panjang (Macaca fascicularis Raffles, 1821), dan beberapa jenis burung.Burung di KKMB berdasarkan hasil inventarisasi dijumpai 18 jenis, sedangkan WWF menemukan 32 jenis (Yusuf, 2008). Sebagai habitat burung, ekosistem mangrove ini digunakan untuk mencari pakan, beristirahat, dan bersarang. Berdasarkan hasil inventarisir, jenis burung yang ada di dalam kawasan konservasi hutan mangrove dan bekantan terdapat 18 jenis burung yaitu: Kuntul kecil (Egretta garzetta Linnaeus), Walet sapi (Collocalia esculenta Linnaeus), Cekakak sungai (Todirhampus chloris Aberh), Kareo padi (Amaurornis phoenicurus Pennant), Kuntul karang (Egretta sacra Gmelin), Bambangan hitam (Dupetor flavicollis), Elang bondol (Haliastur indus Boddaert), Punai bakau (Treron fulvicollis Wagler), Perkutut jawa (Geopelia striata Linnaeus), Dederuk jawa (Streptopelia bitorquata Temminck), Celadi belacan (Dendrocopos canicapillus Blyth), Cucak (Pycnonotus melanoleucos Eyton), Sikatan kepala abu (Culicicapa ceylonensis Swainson), Belibis kembang (Dendrocygna arcuata Horsfield), Bondol rawa (Lonchura malacca Linneaus), Bondol peking (Lonchura punctulata Linneaus), Cabai jawa (Dicaeum trochileum Sparrman), Kipasan belang (Rhipidura javanica Sparrman).

Menurut bapak Abdan dari Kementerian Kelautan dan Perikanan Tarakan, ia menegaskan bahwa:

"pengelolaan ekowisata hutan mangrove sangat penting dilakukan oleh berbagai pihak dan masyarakat. Pemerintah daerah dan instansi terkait, serta masyarakat harus bersinergi dalam mengelola ekowisata hutan mangrove dan bekantan yang mana merupakan kawasan hutan konservasi yang tidak hanya menjadi paru-paru kota dan penangkal abrasi tetapi juga lebih dari pada itu ekowisata hutan mangrove ini jika dikelola dengan baik mampu meningkatkan kesejahteraan perekonomian masyarakat setempat. Dengan adanya manajemen ekowisata hutan mangrove dan bekantan secara otomatis akan membuka peluang usaha bagi masyarakat setempat baik langsung maupun tidak langsung. Namun, berbagai sarana prasarana yang telah di 
bangun di dalam kawasan ekowisata hutan mangrove dan bekantan ini dalam beberapa tahun terakhir tidak beroperasi dengan baik dikarenakan oleh banyak faktor yaitu kurangnya pelibatan masyarakat dalam hal mengelola ekowisata hutan mangrove dan bekantan, defisit anggaran, mengendornya promosi dan edukasi pemerintah daerah, serta kurangnya inovasi pemerintah daerah. Salah satu upaya kami untuk dapat mengajak masyarakat berperan aktif dalam mengelola dan melestarikan ekowisata hutan mangrove dan bekantan ini adalah dengan memberikan program bantuan nelayan pesisir yaitu bantuan mesin, pukat, perahu, dan lain sebagainya, dengan harapan dapat bersamasama menjaga ekowisata hutan mangrove dan bekantan sebagai sebuah kearifan lokal yang wajib dilindungi dan dilestarikan".

Pada awalnya pengelolaan hutan mangrove dan bekantan sebagai hutan konservasi dan ekowisata berjalan baik dengan dibangunnya berbagai fasilitas didalamnya. Namun, pada tahun 2016, manajemen hutan mangrove mengalami penurunan dari berbagai sektor baik tangible maupun intangible. Sehingga, pengelolaan hutan mangrove diambil alih oleh pemerintah provinsi Kaltara terutama dalam hal pengelolaan pajak retribusi ekowisata hutan mangrove. Meskipun ekowisata hutan mangrove dan bekantan diambil alih, tidak membawa perubahan yang signifikan. Ekowisata hutan mangrove dan bekantan kota Tarakan berjalan ditempat dan tidak ada kemajuan. Hingga kini kondisi ekowisata hutan mangrove dan bekantan ini mengalami penurunan jumlah pengunjung, oleh karena itu, perlu adanya pengelolaan secara otonomi kepada pemeritah daerah serta pelibatan peran aktif masyarakat setempat. Karena masyarakat setempat lebih mengetahui kondisi dan iklim yang ada di kawasan ekowisata hutan mangrove dan bekantan. Dengan melibatkan masyarakat dalam pengelolaan, pengawasan, dan pelestarian baik berupa program penanaman bibit, perawatan, hingga mengembangkan softskill masyarakat sehingga akan terjadi proses saling membutuhkan (simbiosis mutualisme) yamg akan berdampak pada meningkatkan kesejahteraan masyarakat setempat.

2.Dinas Pariwisata

Dinas Pariwisata juga memiliki peran yang strategis dalam mendukung pelestarian ekowisata hutan mangrove dengan melakukan berbagai kegiatan-kegiatan pariwisata yang melibatkan masyarakat secara langsung baik berupa sosialisasi, informasi dan promosi maupun edukasi. Kegiatan kepariwisataan yang dapat dilakukan yaitu tidak hanya adanya pelayanan wisata alam kepada para pengunjung lokal maupun mancanegara dengan menyiapkan berbagai fasilitas jasa transportasi pelayanan tetapi juga perlu adanya kegiatan pelatihan dan pembinaan kepada masyarakat sekitar dalam mengolah sumber daya alam hutan mangrove sebagai kerajinan tangan. Kerajinan tangan ini bisa berupa pengolahan bahan baku hutan mangrove sebagai oleh-oleh berupa olahan makanan, minuman, souvenir, dan obat-obatan, sehingga menjadi daya jual masyarakat lokal kepada para pengunjung. Dengan adanya upaya dan starategi peningkatan peran masyarakat melalui dinas pariwisata ini akan tercipta suatu masyarakat yang peduli dengan pelestarian hutan mangrove mengingat peran masyarakat semakin strategis baik dalam pengelolaan, pengwasan maupun pelestariannya, karena sumber pendapatan masyarakat berasal dari ekowisata hutan mangrove. Namun, kondisi yang ada di masyarakat sekitar ekowisata hutan mangrove Kota Tarakan dewasa ini kurang terlibat dalam hal pemberdayaan oleh pemerintah, masyarakat hanya berupaya sendiri mencari peluang usaha akan adanya ekowisata hutan mangrove dan tidak terlibat langsung didalamnya. Oleh karena itu ke depan peran masyarakat perlu ditingkatkan, dan Dinas Pariwisata Kota Tarakan perlu melakukan strategi-strategi peningkatan dalam upaya melestarian ekowisata hutan mangrove dan bekantan sehingga menjadi daya tarik dan daya jual kepada para pengunjung. Hal ini sebagaimana diungkapkan oleh ibu Sucia yang merupakan staf Dinas Pariwisata Kota Tarakan. "Memang sampai saat ini kegiatan kepariwisataan terhadap kawasan ekowisata hutan mangrove dan bekantan hanya sebatas kunjungan wisata alam kepada para pengunjung yang datang baik lokal maupun mancanegara. Pada tahun 2005 hingga tahun 2013 kondisi wisata alam hutan mangrove dan bekantan ini masih beroperasi dengan baik, namun ketika peralihan dan pergantian kepemimpinan di pemerintahan turut mengakibatkan mengendurnya kegiatan pelestarian kawasan hutan mangrove dan bekantan kota Tarakan. Dulu pada masa jayanya hutan mangrove sebagai icon wisata alam yang ada di pusat kota Tarakan, kami banyak melakukan berbagai upaya sosialisasi dan promosi baik melalui media cetak (koran) maupun media elektronik 
(televisi dan radio) sehingga masyarakat lokal, nasional hingga mancanegara banyak mengetahui tentang keberadaan sebuah kawasan hutan mangrove dan bekantan yang ada di pusat kota, hal ini menjadi daya tarik kunjungan wisatawan. Ke depan upaya peningkatan pelestarian ekowisata hutan mangrove dan bekantan di kota Tarakan ini perlu ditingkatkan kembali dengan merevitalisasi dan merekonstruksi berbagai fasilitas pendukung didalamnya, juga melibatkan peran aktif masyarakat lokal terutama peningkatan kualitas sumber daya manusia berupa pelatihan dan pembinaan soft skill dalam membuat kerajinan tangan dengan menggunakan bahan dasar hutan mangrove sebagai olahan yang berdaya jual baik berupa olahan makanan, minuman, souvenir, maupun obat-obatan yang tentu akan berdampak langsung pada peningkatan ekonomi daerah dan kesejahteraan masyarakat setempat."

Mengingat pentingnya ekowisata alam kawasan konservasi hutan mangrove dan bekantan (KKMB) sebagai objek wisata yang dimiliki kota Tarakan yang keberadaannya sangat strategis di pusat kota merupakan asset yang tidak hanya menjadi paru-paru perkotaan dan mencegah adanya abrasi air laut juga sebagai pusat wisata alam yang memiliki keindahan dengan keanekaragaman fauna dan flora didalamnya. Sehingga hal ini menjadi nilai jual yang tidak hanya menjadi destinasi wisata tetapi mampu mendongrak perekonomian daerah dan meningkatkan kesejahteraan masyarakat lokal. Untuk itu, peran dinas pariwisata sebagai komponen pemerintah daerah yang bertugas menciptakan potensi budaya lokal daerah sebagai pusat kepariwisataan sudah seyogyanya dinas pariwisata melakukan berbagai upaya dan langkah strategis dalam meningkatkan perannya baik dalam hal penyediaan sarana dan prasarana layanan maupun melakukan promosi di berbagai media baik cetak maupun elektronik. Sehingga, ekowisata hutan mangrove ini bisa mendatangkan gelombang wisatawan lokal, nasional, maupun mancanegara yang secara otomatis dapat menciptakan peran aktif masyarakat dan seluruh unsur pemerintah dalam melestarikan ekowisata hutan mangrove sebagai asset wisata yang bernilai bagi kehidupan masyarakat.

3.Pegawai KKMB

Selain peran pemerintah di atas, pegawai Kawasan Konservasi Hutan Mangrove dan Bekantan (KKMB) Kota Tarakan juga memiliki peran strategis dalam mengelola, menjaga, dan mengawasi ekowisata hutan mangrove dan bekantan. Karena mereka yang terlibat secara langsung dalam menjaga kondisi hutan mangrove dan bekantan agar tetap kondusif, aman dan nyaman dikunjungi masyarakat. Namun, pegawai KKMB ini tidak bisa berperan banyak dalam hal pembiayaan dan pendanaan, karena mereka hanya bertugas untuk mengelola dan menjaga, sehingga semua tata manajemen berada di tangan pemerintah daerah. Pengelola KKMB hanya diberikan tugas memungut biaya retribusi pengunjung yang masuk serta merawat $\mathrm{KKMB}$, terkait perihal biaya perawatan itu merupakan wewenang pemerintah daerah. Apalagi pada dasawarsa lima tahun terakhir kondisi keuangan pemerintah pusat hingga daerah mengalami defisit anggaran yang menyebabkan banyaknya program-program daerah yang terbengkalai akibat minimnya anggaran khususnya anggaran perawatan dan pengembangan ekowisata hutan mangrove dan bekantan Kota Tarakan. Terkait dengan peran penjaga atau pegawai KKMB dalam melestarikan kawasan konservasi hutan mangrove kota Tarakan, sebagaimana diungkapkan oleh bapak Samsul yang merupakan koordinator penjaga kawasan konservasi mangrove dan bekantan (KKMB) kota Tarakan mengungkapkan:

"Peran kami dalam pelestarian ekowisata hutan mangrove dan bekantan (KKMB) kota Tarakan hanya sebatas mengelola KKMB dari segi perawatan dan pengawasan terutama terkait memberikan pakan monyet bekantan setiap hari dan biaya retribusi pengunjung yang masuk ke kawasan konservasi hutan mangrove dan bekantan (KKMB). Biaya retribusi ini hanya sebatas kami kumpulkan dan nanti akan disetorkan ke pihak pemerintah melalui Badan Pengelola Pajak dan Retribusi Daerah (BPPRD) Provinsi Kalimantan Utara. Biaya retribusi dalam sebulan bisa terkumpul sebesar Rp. 11.000.000,- dengan rata-rata kunjungan masyarakat baik lokal maupun mancanegara dalam seminggu sekitar 200-300 orang pada waktu libur (Minggu). Kemudian dalam satu tahun kunjungan bisa mencapai 24.000 orang. Sedangkan pegawai KKMB ini ada sekitar 14 orang, laki-laki 9, perempuan 5 orang dengan gaji yang beragam tergantung tingkat pendidikan. Pendidikan Sarjana digaji Rp.2.600.000,- dan Pegawai SMA Rp. $1.050 .000,-$. Sistem penggajian ini sesuai dengan aturan keuangan Provinsi Kalimantan 
Utara. Penggajian gaji pegawai KKMB melalui Dinas Kehutanan Provinsi Kalimantan Utara. Karena KKMB saat ini sudah diambil alih oleh Dinas Kehutanan Kalimantan Utara. Meskipun ada kabar tahun 2020 akan kembali diambil alih oleh Dinas Kehutanan Kota Tarakan. Terkait perawatan sarana perasaran dalam 10 tahun terakhir sudah tidak diperhatikan lagi oleh pemerintah terkait diakrekana berbagai faktor, kecuali ketika ada kegiatan APEKSI yang pada waktu itu Tarakan sebagai tuan rumah ada sedikit perbaikan dari pemerintah. Perbaikan ini hanya sebatas pengecetan ulang KKMB namun tidak menyentuh sampai kepada kawasan hutan mangrove dan sarana prasarana didalamnya secara keseluruhan."

Berdasarkan ungkapan di atas, maka dapat diketahui bahwa pengelolaan ekowisata hutan mangrove tidak berjalan satu pintu, sehingga hal ini menjadi permasalahan dalam melakukan pengelolaan kawasan konservasi hutan mangrove dan bekantan (KKMB) sebagai objek wisata alam. Terutama permasalahan sarana dan prasarana yang tidak terawat dengan baik sehingga hal ini menjadi salah satu penyebab rendahnya kunjungan wisatawan baik lokal maupun mancanegara, karena kurangnya kenyamanan dan minimnya daya tarik yang menjadi nilai jual adanya ekowisata hutan mangrove dan bekantan. Untuk itu, pengelolaan yang baik yang berasaskan pada prinsip informatif dan edukatif menjadi hal penting dalam menjadikan ekowisata hutan mangrove sebagai satu-satunya kunjungan wisata alam yang patut diperhitungkan dan menguntungkan dearah dan masyarakat lokal.

4.Pedagang

Kawasan Konservasi Hutan Mangrove dan Bekantan (KKMB) berada di kawasan pusat perdagangan. Banyak para pedagang yang mendapatkan keuntungan dari keberadaan KKMB. Dengan adanya KKMB para pedagang memperoleh peningkatan pendapatan dengan banyaknya para pengunjung yang berkunjung ke KKMB. Beberapa diantaranya adalah ibu Ros (penjual makanan) yang tinggal di Karang Anyar dan memiliki warung di Jalan Gadjah Mada (Gusher) yang menjual nasi kuning, soft drink, es teh dan berbagai makanan lainnya. Ibu Ros mengungkapkan bahwa:

"Keberadaan KKMB memiliki dampak kepada para pedagang, salah satunya saya sebagai penjual makanan dan minuman terutaman ketika hari libur anak sekolah tiba atau ketika hari libur (Minggu). Pendapatan ketika hari minggu mengalami peningkatan signifikan. Biasanya pada hari-hari kerja, pembeli biasanya berkisar 10-15 orang perharinya. Ketika pada waktu liburan (Minggu) terjadi peningkatan pembeli sekitar 30-40 orang dengan harga nasi kuning Rp. 20.000,-, soft drink Rp.4.000,-, es teh, Rp. 5.000,-. Jika dikalkulasikan dalam waktu libur (Minggu) keuntungan yang didapatkan bisa mencapai Rp. $870.000,-$. Jika dihitung dalam waktu seminggu bisa mencapai keuntungan Rp. 1.500,000-Rp. 2.000.000,- per minggunya. Namun, keuntungan ini tidak bisa bersifat tetap tergantung situasi dan kondisi, apalagi ketika musim hujan tiba tentu pengunjung tidak akan sama seperti ketika kondisi lagi cerah serta berbagai kondisi lainnya. Jadi keuntungan ini tidak bersifat tetap, namun secara keseluruhan saya mendapatkan keuntungan dengan keberadaan KKMB. Maka dari itu, salah satu upaya saya melestarikan ekowisata hutan mangrove dengan memberikan layanan yang terbaik kepada para wisatawan yang berkunjung ke KKMB dengan menyediakan makanan dan minuman yang berkualitas serta memberikan informasi dan penunjuk arah kepada wisatawan yang berkunjung ke KKMB. "

Senada dengan ungkapan di atas, Bapak Sujiono yang kesehariannnya sebagai pedagang Es Dawet juga merupakan pegawai Swiss Bell Hotel menuturkan bahwa:

"Keberadaan konservasi hutan mangrove dan bekantan secara langsung memberikan dampak peningkatan pendapatan bagi saya yang berjualan di kawasan ekowisata hutan mangrove dan bekantan seputar jalan Gadjah Mada (Gusher) Tarakan Barat. Para wisatawan yang berkunjung ke KKMB pada waktu libur atau hari minggu kebanyakan adalah para pelajar dan mahasiswa serta para keluarga, sehingga pada waktu liburan tiba konsumen yang datang untuk membeli es dawet sekitar 20-30 orang dengan satu gelas es dawet seharga Rp. 5.000,-, jika dikalkulasikan dalam sehari (khususnya di hari Minggu) pendapatan saya bisa mencapai Rp. 300.000,-. Belum lagi ditambah hari-hari lainnya, bisa mendapatkan sekitar Rp.500.000 sd 800.000 per minggunya. Namun, kisaran pendapatan ini tidak bisa menjadi patokan, kalau berdagang itu kadang ramai dan kadang juga sepi, tergantung situasi dan kondisi.

Berdasarkan wawancara di atas, dapat disimpulkan bahwa peran pedagang dalam pelestarian ekowisata hutan mangrove dan bekantan (KKMB) sangat diperlukan karena 
dengan adanya para pedagang, para pengunjung dapat dengan mudah memperoleh makanan dan minuman. Akan tetapi, para pedagang ini lebih banyak beraktivitas di luar kawasan ekowisata bukan di dalam kawasan ekowisata hutan mangrove dan bekantan (KKMB) dengan mengisi berbagai gazebo-gazebo atau standstand jualan yang dulu sempat digunakan oleh masyarakat sekitar. Namun, sekarang gazebogazebo atau stand-stand jualan itu sudah tidak beroperasi lagi. Maka dari itu, ke depan perlu adanya peningkatan peran masyarakat sekitar untuk dapat terlibat dalam kegiatan pengelolaan dan memfungsikan kembali sarana prasarana di dalak kawasan ekowisata hutan mangrove dan bekantan (KKMB) sehingga dengan begitu masyarakat dapat berjualan dan turut berkontribusi dalam melakukan pengawasan dan pelestarian.

5.Masyarakat

Dari hasil pengamatan dan wawancara yang dilakukan, peran masyarakat yang ada di sekitar kawasan konservasi hutan mangrove cukup beragam. Dari segi pekerjaan, masyarakat kawasan konservasi hutan mangrove ini ada yang bekerja sebagai pegawai negeri sipil (pns), pegawai swasta, pedagang, nelayan, petambak, dan pelajar. Dari beberapa jenis pekerjaan masyarakat sekitar kawasan konservasi hutan mangrove dan bekantan (KKMB) yang banyak dilakukan oleh masyarakatnya adalah bekerja sebagai petambak, nelayan, pedagang, dan pegawai swasta, karena berhubung kawasan ini merupakan pusat kota yang di sekitarnya banyak pusat-pusat perbelanjaan dan perusahaan, serta berada di pesisir pantai maka pekerjaan yang dominan digeluti oleh masyarakatnya adalah sebagai petambak, pedagang, nelayan dan pegawai swasta. Meskipun ada yang bekerja sebagai pegawai negeri sipil (PNS), namun jumlahnya sedikit. Jika melihat fenomena ini, nampak sekali bahwa tingkat pendidikan masyarakat di kawasan ini sangatlah rendah, melihat sedikitnya daya serap masyarakat di dunia kerja di lembaga pemerintahan.

Pengelolaan hutan mangrove sebagai wahana konservasi dan sekaligus ekowisata tidak hanya tanggung jawab dan peran dari pemerintah saja, tetapi masyarakat sekitar juga dilibatkan sebagai pengelola dalam melestarikan hutan mangrove. Peran pengelolaan dan pelestarian tersebut biasanya dilakukan dengan cara melakukan penanaman bibit hutan mangrove (restorasi hutan mangrove) yang tentunya salah satu program dari pemerintah sebagai pengelola utama dan kemudian melibatkan masyarakat sekitar untuk dapat turut serta dalam melakukan penanaman dan pembibitan hutan mangrove. Adanya restorasi hutan mangrove karena adanya penebangan pohon mangrove oleh oknumoknum yang tidak bertanggungjawab sehingga upaya restorasi hutan mangrove perlu digalakkan. Dengan dilibatkannya masyarakat sekitar sebagai pengelola maka secara otomatis masyarakat sekitar akan timbul kesadaran untuk bersama-sama menjaga dan melestarikan konservasi ekowisata hutan mangrove. Tentu dengan adanya pelibatan peran masyarakat ini maka akan muncul rasa memiliki (sense of belonging) akan hutan mangrove, terlebih masyarakat sekitar kawasan hutan mangrove yaitu kawasan karang rejo dan sekitarnya sangat bergantung kepada hutan mangrove khususnya masyarakat sekitar yang bekerja sebagai nelayan. Dengan berkualitasnya hutan mangrove maka akan berbanding lurus dengan hasil laut yang ada disekitar kawasan hutan serta meningkatnya hasil tangkapan mereka di pesisir laut yang juga berdampak pada peningkatan perekonomian masyarakat sekitar. Karena di kawasan laut sekitar mangrove hidup berbagai biota laut yang merupakan sumber penghasilan masyarakat sekitar seperti ikan, kepiting, udang, dan lain sebagainya. Hal ini senada dengan ungkapan bapak Ibrahim yang sehari-hari bekerja sebagai seorang nelayan pesisir kawasan hutan mangrove ia mengatakan bahwa:

"Hutan mangrove memiliki dampak yang cukup besar bagi para nelayan, dengan dikelolanya hutan mangrove secara baik dan benar maka hal ini akan dirasakan masyarakat sekitar. Salah satunya adalah dengan adanya penanaman bibit hutan mangrove secara berkelanjutan dengan melibatkan peran serta masyarakat sekitar yang memang begitu memahami kawasan hutan mangrove baik secara geografis maupun ekonomis. Dengan adanya pelibatan masyarakat sebagai pengelola dalam hal melakukan penanaman dan pembibitan yang juga bersinergi dengan pemerintah yang juga bagian dari masyarakat di pemerintahan yang membidangi instansi terkait mengenai pelestarian hutan mangrove maka cita-cita menjadikan hutan mangrove kota Tarakan sebagai paru-paru hutan di perkotaan tidak hanya berdampak pada terciptanya ekowisata yang menarik kunjungan wisatawan tetapi juga mampu mensejahterakan masyarakat sekitarnya dan juga meningkatkan devisa daerah. Tidaknya hanya itu, lestari dan berkualitasnya hutan mangrove juga berdampak 
pada berkualitasnya jumlah biota laut yang ada di sekitar kawasan pesisir laut yang secara otomatis akan berdampak pada meningkatnya jumlah pendapatan masyarakat nelayan. Peran masyarakat dalam melestarikan ekowisata hutan mangrove adalah dengan menjaga kebersihan hutan mangrove dan melakukan pengawasan terhadap hutan mangrove dari adanya oknum ilegal loging penebangan hutan mangrove".

Tidak hanya itu, pendapat lain datang dari seorang Guru yang tinggal di kawasan ekowisata hutan mangrove dan bekantan, ia berujar:

"Setiap individu masyarakat berkewajiban menjaga dan melestarikan ekowisata hutan mangrove dan bekantan (KKMB), karena hutan KKMB memiliki manfaat yang banyak bagi masyarakat. Manfaatnya tidak hanya sebagai parau-paru perkotaan dan pencegah banjir dan abrasi tetapi jauh lebih dari itu hutan mangrove dan satwa endemik didalamnya memiliki berbagai khasiat bagi kelangsungan kehidupan manusia. Buah hutan mangrove dengan berbagai kelebihannya memiliki manfaat dan kegunaan yang bisa diolah menjadi makanan, minuman bahkan obat-obatan. Ada banyak riset yang menyatakan bahwa hutan mangrove baik batang, daun dan buahnya berkhasiat sebagai obat berbagai penyakit. Misalnya Avicennia Alba merupakan salah satu jenis pohon mangrove yang batangnya bisa menghilangkan rematik, cacar, dan borok. Sedangkan Avicennia Offinalis pada buah, daun dan akarnya berkhasiat mengobati hepatitis dan batangnya berkhasiat sebagai anti tumor. Melihat berbagai khasiat dari hutan mangrove ini tentu dibutuhkan peran aktif masyarakat untuk dapat berpartisipasi dalam mengelola dan melestarikan ekowisata hutan mangrove supaya terus lestari. Sehingga, hutan mangrove menjadi hutan yang wajib dilindungi oleh seluruh lapisan masyarakat."

Berpijak dari penryataan di atas, maka dapat diketahui bahwa hutan mangrove memiliki potensi yang luar biasa, tidak hanya sebagai paru-paru perkotaan dan pencegah banjir serta abrasi tetapi menjadi alternatif kuliner yang sehat dan menyehatkan. Hutan mangrove baik batang, daun dan buahnya bisa diolah sebagai makanan, minuman, dan obat-obatan yang berfungsi bagi manusia. Minimnya edukasi mengenai manfaat dan khasiat hutan mangrove ini harus mampu disambut baik oleh pemerintah daerah untuk dapat melakukan berbagai riset untuk dapat mengetahui fungsi hutan mangrove bagi manusia. Salah satu media yang bisa lakukan pemerintah adalah dengan mengadakan workshop atau pelatihan mengelola sumber daya hutan mangrove sebagai bahan kerajinan tangan, olahan makan dan minuman, serta dapat dijadikan obat-obatan yang bisa dikembangkan dalam dunia medis herbalis sebagai alternatif pengobatan.

Analisis SWOT

Berdasarkan peran yang dimainkan masyarakat yang berada di Kawasan Konservasi Hutan Mangrove yang berada di kelurahan Karang Rejo Tarakan Barat, maka untuk menemukan strategi peningkatan peran masyarakat dalam melestarikan kearifan lokal ekowisata hutan mangrove dilakukan dengan menggunakan metode analisis SWOT (Strenghts, Weaknessess, Opportunities, dan Threats). Sebagai langkah awal dilakukan pemilihan faktor internal dan eksternal, kemudian selanjutnya disusunlah strategi peningkatan peran masyarakat dalam melestarikan kearifan lokal ekowisata konservasi hutan mangrove dan bekantan (KKMB) kelurahan Karang Rejo Tarakan Barat. Adapun analisis faktor internal dan eksternal serta strategi peningkatan peran masyarakat dalam melestarikan kearifan lokal ekowisata hutan mangrove digambarkan dalam bentuk tabel berikut:

Berdasarkan analisis internal dan eksternal tersebut di atas, maka ditemukan strategi peningkatan peran masyarakat dalam melestarikan kearifan lokal ekowisata hutan mangrove sebagai berikut: (1) Revitalisasi Sarana Prasarana (Sanpras) KKMB agar lebih produktif dan menarik; (2) Melakukan pelatihan soft skill kepada masyarakat tentang pemanfaatan hutan mangrove; (3) Melakukan promosi ekowisata KKMB melalui media cetak maupun media elektronik; (4) Melakukan kerjasama dengan seluruh stakeholder dalam mendukung pelestarian hutan mangrove, dan; (5) Mengembangkan industri produk kerajinan (sovenir), makanan, dan obat-obatan dari bahan baku mangrove.

Strategi Peningkatan Peran Masyarakat dalam Melestarikan Ekowisata Mangrove dan Bekantan di Kelurahan Karang Rejo Tarakan Barat

1. Revitalisasi Sarana dan Prasarana Ekowisata Mangrove dan Bekantan 
Salah satu faktor pendukung ekowisata kawasan konservasi hutan mangrove dan bekantan (KKMB) adalah terletak pada sejauhmana sarana prasarana yang ada di dalam hutan mangrove bisa berjalan secara produktif, kreatif, informatif, dan juga bernilai edukatif sehinga lebih menarik bagi para pengunjung dan masyarakat. Dengan adanya upaya pemerintah, stakeholder, dan masyarakat dalam menciptakan kondisi ekosistem hutan mangrove menjadi lebih produktif dan memiliki nilai eksotisme yang menarik bagi wisatwan maka secara otomatis hal ini akan meningkatkan jumlah

\begin{tabular}{|c|c|c|}
\hline Ekstemal \} $&{\text { 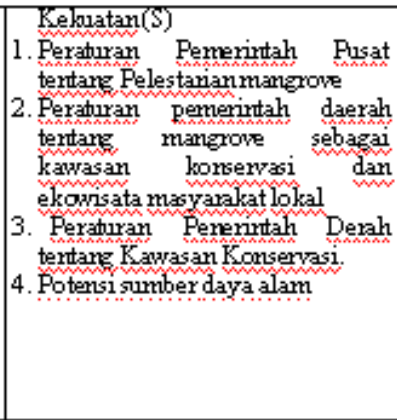 }} &{\text { 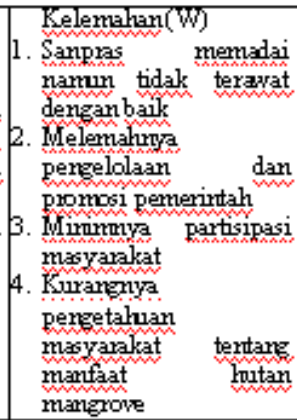 }} \\
{\hline \text { 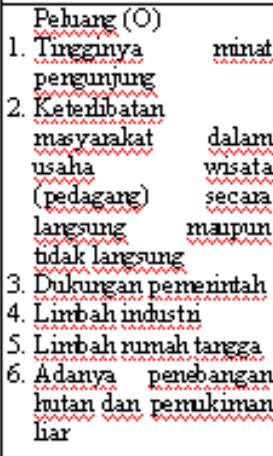 }} &{\text { 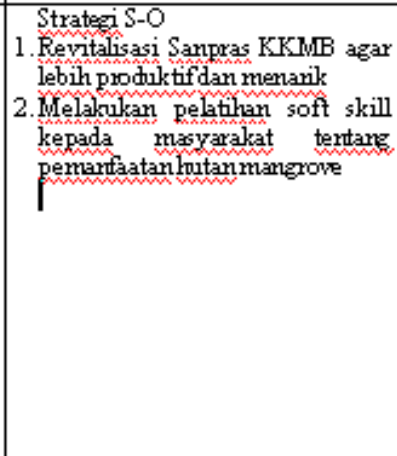 }} &{\text { 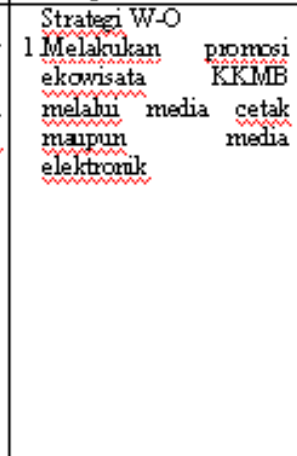 }} \\
{\hline \text { 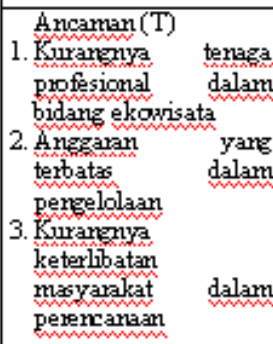 }} &{\begin{array}{l}\text { Strategis-T } \\
\text { 1. Melakukan keriacama dengan } \\
\text { sehunh stakeholder dalam } \\
\text { menthikurg pelestarian hutam } \\
\text { mangrone }\end{array}} &{\text { 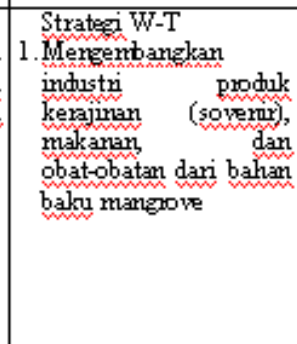 }} \\
$\hline
\end{tabular}

pengunjung baik dari lokal maupun mancanegara. Sehingga dengan begitu, secara otomatis akan mendongkrak devisa dan sirkulasi perekonomian kota Tarakan secara sehat dan berkelanjutan.

2.Pelatihan Softskill kepada Masyarakat

Banyak masyarakat yang belum mengetahui tentang manfaat dan fungsi hutan mangrove bagi kehidupan manusia, terutama pemanfaatannya bagi kebutuhan masyarakat lokal. Hanya sedikit pengetahuan masyarakat mengenai manfaat dan khasiat dari hutan mangrove. Oleh karena itu, untuk memasyarakatkan hutan mangrove maka perlu melakukan pelatihan softskill kepada masyarakat tentang bagaimana cara memanfaatkan hutan mangrove dalam kehidupan. Pelatihan ini bertujuan untuk dapat memberikan informasi dan mengedukasi masyarakat tentang pentingnya melestarikan hutan mangrove karena hutan mangrove memiliki banyak manfaat yang berguna bagi masyarakat lokal. Pelatihan ini tentunya melibatkan berbagai pihak baik pemerintah, para peneliti, para ahli maupun stakeholders maupun masyarakat sehingga masyarakat mampu membuat berbagai kreasi berupa hasil olahan kerajinan tangan dengan bahan dasar hutan mangrove seperti membuat kerajinan berupa souvenir, olahan makanan dan minuman maupun obat-obatan yang tentunya membutuhkan penelitian dan pengembangan yang berkelanjutan. Untuk itu, pemerintah dapat bekerjasama dengan stakeholder profesional (akademisi atau praktisi) yang bergerak di bidang pelatihan softskill kewirausahaan dengan memanfaatkan hutan mangrove sebagai bahan kajian dan penelitian untuk menemukan bahanbahan dari ekosistem hutan mangrove yang dapat dikelola untuk menjadi sebuah produk yang dapat di pasarkan di daerah lokal, nasional, hingga internasional. Dengan adanya pelatihan softskill kewirausahaan pada tanaman mangrove secara otomatis memberikan ilmu dan informasi kepada masyarakat lokal akan fungsi dan manfaat mangrove yang jarang diketahui orang untuk menciptakan pelung usaha di bidang pariwisata ekologi hutan mangrove.

3.Promosi Ekowisata Mangrove dan Bekantan Melalui Media

Ekowisata hutan mangrove kini mulai kehilangan kepopulerannya sebagai salah satu wisata alam pesisir yang banyak diminati oleh wisatawan. Oleh kaena itu, promosi secara terus-menerus perlu dilakukan oleh pemerintah dan masyarakat baik melalui media cetak maupun elektronik agar ekowisata hutan mangrove kota Tarakan menjadi icon pariwisata yang bisa menghipnotis wisatawan lokal, regional maupun mancanegara dengan keindahan hutan tropisnya maupun fauna dan biota laut yang beragam seperti banyaknya ragam hutan mangrove, burung, kepiting, ikan, dan lain sebagainya yang menjadi pelengkap panorama wisata alam pesisir yang berada di pusat kota ini. Promosi ini bertujuan agar masyarakat dan wisatawan mengetahui akan 
adanya kawasan konservasi hutan mangrove dan bekantan di pusat kota yang tentunya menjadi keunikan tersendiri, hal ini terbukti dengan adanya promosi menggunakan media cetak maupun elektronik akan menambah jumlah wisatawan yang bertandang ke Kota Tarakan. Dengan banyaknya wisatawan yang datang akan berkorelasi dengan meningkatkan devisa daerah yang juga berimplikasi pada peningkatan kesejahteraan masyarakat lokal.

4.Kerjasama Dengan Seluruh Stakeholders

Pelestarian ekowisata hutan mangrove tidak akan tercapai jika tanpa adanya kerjasma dari seluruh stakeholders baik pemerintah, perusahaan, lembaga pendidikan, dan pusat penelitian, maupun masyarakat lokal. Dengan adanya sinergi dari berbagai pihak pelestarian hutan mangrove akan dapat berjalan dengan baik. Kerjasama ini bisa berupa penanaman bibit-bibit jenis baru untuk melengkapi keanekaragaman hayati serta memaksimalkan sistem pengelolaan ekowisata hutan mangrove terutama dalam hal perawatan dan pengembangan ekowisata hutan mangrove. Adanya kerjasama berbagai pihak dapat mensupport suksesnya pelestarian ekowisata hutan mangrove sebagai wujud optimalisasi peran serta masyarakat dalam hal pengelolaan dan pelestarian serta pengawasan secara berkelanjutan baik sebagai objek wisata maupun pusat penelitian berbagai lembaga pendidikan. Saat ini, pemerintah telah melakukan berbagai upaya dalam meningkatkan pertumbuhan perekonomian di kota Tarakan, salah satunya menggunakan badan jalan di depan Kawasan Konservasi Hutan Mangrove dan Bekantan (KKMB) sebagai pusat kuliner (pasar malam) dengan metode pembayaran non tunai berbasis online melalui media android (dompet digital) seperti Go-Pay, Ovo, dan lain sebagainya sebagai wujud menciptakan Tarakan menjadi Smart City.

5.Mengembangkan Industri Produk Kerajinan Lokal Masyarakat

Dengan adanya mengetahui potensi-potensi hutan mangrove dengan adanya pelatihan softskill kewirausahaan di bidang hutan mangrove, maka perlu dikembangkan indsutri produk kerajinan (souvenir), olahan makanan dan minuman serta obat-obatan dari proses ekstraksi buah mangrove. Sedikitnya masyarakat yang memanfaatkan buah mangrove sebagai bahan pangan, kecantikan (kosmetik), bahkan produk obat-obatan ditengarai oleh kurangnya pemahaman mssyarakat terhadap manfaat dan khasiat hutan mangrove. Padahal, begitu banyak manfaat yang terdapat di dalam buah mangrove yang dapat digunakan oleh masyarakat dalam meningkatkan perekonomian mereka baik untuk dikonsumsi sendiri maupun diperdagangkan. Berdasarkan hasil penelitian, pemanfaatan buah mangrove sebagai sumber pangan sudah dilakukan oleh masyarakat sekitar, namun hanya dilakukan pada wilayah tertentu dan oleh sebagian kecil masyarakat. Menurut Haryono (2004) sebagaimana dikutip oleh IPB (diunduh 10 Oktober 2019) buah mangrove jenis Lindur (Brugniera Gymnorrhiza) dikonsumsi sebagai campuran nasi atau jagung. Sementara di Muara Angke Jakarta dan di Teluk Balikpapan buah mangrove jenis Api-Api (Aviecennia Alba) diolah menjadi kripik, Aviecennia sp bisa diolah menjadi tepung, sementara itu buah mangrove jenis Papeda (Sonneratia Alba) diolah menjadi sirup, dodol, dan permen. Upaya untuk memasyarakatkan pengetahuan, pemahaman, dan keterampilan tentang manfaat buah mangrove perlu digalakkan oleh pemerintah kota Tarakan, mengingat banyak jenis hutan mangrove yang ada di kawasan konservasi hutan mangrove dan bekantan (KKMB) yang bisa diolah menjadi produk pangan, kosmetik, maupun obat-obatan. Untuk bahan obat-obatan, Aviecennia Alba (buah Api-Api) bisa diekstrak menjadi obat rematik, cacar, dan borok. Sedangkan Nypa fructicans (pohon nipah) bisa diolah menjadi obat sinusitis (batang dan kulit batang). Melihat banyaknya manfaat dari hutan mangrove ini tentu menjadi produk lokal yang bernilai jual tinggi baik di skala nasional maupun internasional jika pemerintah, stakeholder, dan masyarakat bersinergi dalam memasyarakatkan manfaat serta khasiat dari hutan mangrove.

\section{KESIMPULAN}

Hasil penelitian ditemukan beberapa strategi peningkatan peran masyarakat dalam melestarikan kearifan lokal ekowisata hutan mangrove yaitu; (1) Revitalisasi Sarana Prasarana (Sanpras) KKMB agar lebih produktif dan menarik; (2) Melakukan pelatihan soft skill kepada masyarakat tentang pemanfaatan hutan mangrove; (3) Melakukan promosi ekowisata KKMB melalui media cetak maupun media elektronik; (4) Melakukan kerjasama dengan seluruh stakeholder dalam mendukung pelestarian hutan mangrove, dan; (5) 
Mengembangkan industri produk kerajinan tangan masyarakat (sovenir), makanan, dan obat-obatan dari bahan baku mangrove.

\section{UCAPAN TERIMA KASIH}

Terima kasih kepada Dekan Fakultas Pertanian, Dr. Etty Wahyuni, S.Hut.,MP, Ketua Lembaga Penelitian dan Pengabdian Masyarakat (LP3M), Dr. Syahran, SE.,M.Sc, serta berbagai pihak instansi pemerintah dan masyarakat di tempat penelitian yang sudah membantu dalam mensukseskan kegiatan ini.

\section{DAFTAR PUSTAKA}

Alfian, Magdalia. 2013. Potensi Kearifan Lokal dalam Pembentukan Jati Diri dan Karakter Bangsa, Prosiding The 5 Thn ICSSIS: "Etnicity and Globalization", di Yogyakarta pada tanggal 13-14 Juni 2013.

Bakir,R. Suyoto. 2014. Kamus Lengkap Bahasa Indonesia. Karisma Publishing Group. Tangerang.

Emma Hijriati dan Rina Mardina. 2014. Pengaruh Ekowisata Berbasis Masyarakat Terhadap Perubahan Kondisi Ekologi, Sosial, dan Ekonomi di Kampung Batusuhanan, Sukabumi, Jurnal Sodality,

Fajriani, U. 2014. Peranan Kearifan Lokal dalam Pendidikan Karakter, Sosio Dialektika, Social and Science Education Journal, Vol. 1, No. 2,

Koentjaraningrat. 2013.Pengantar Ilmu Antropologi. Aksara Baru.Jakarta

Murianto, dkk. 2018.Strategi Pengembangan Ekowisata Berbasis Masyarakat Lokal di Teluk Seriwe Lombok Timur, Jurnal Media Bina Ilmiah, Vol. 13, No. 2.

Nasution. 2002. Metodologi Penelitian. Penerbit Bumi Aksara. Jakarta

Sarlito Wirawan Sarwono. 2015. Teori-Teori Psikologi Sosial. Rajawali Press. Jakarta

Satria, Dias. 2009. Strategi Pengembangan Ekowisata Berbasis Ekonomi Lokal dalam Rangka Program Pengentasan Kemiskinan di Wilayah Kabupaten Malang, Journal of Indonesian Applied Economics, Vol. 3, No 1

Setiadi, Elly M. 2015. Ilmu Sosial dan Budaya Dasar, Kencana Prenada Media Group. Jakarta

Soekamto, Soerjono. 2002. Sosiologi Suatu Pengantar. Rajawali Press. Jakarta
Suhardono, Edy, 2014.Teori Peran (Konsep, Derivasi dan Implikasinya). PT. Gramedia Pustaka Utama.Jakarta

Sugiyono. 2011. Metode Penelitian Kuantitatif Kualitatif dan R\&D. Alfabeta. Bandung.

Taqwa, A. 2010. Analisis produktivitas primer fitoplankton struktur komunitas fauna maktrobenthos berdasarkan kerapatan mangrove di KKMB, Kota Tarakan, Kalimantan Timur. [Tesis]. Program Studi Magister Manajemen Sumberdaya Pantai, Universitas Diponegoro [Indonesia] Diakses 14 Pebruari 2013 dari hal.http://eprints.undip .ac.id/23802/1/Amrullah_Taqwa.pdf.

Wibowo, Agus \& Gunawan. 2015. Pendidikan Karakter Berbasis Kearifan Lokal di Sekolah. Pustaka Belajar. Yogyakarta.

Wiharyanto, D. 2007. Kajian Pengembangan Ekowisata Hutan Mangrove di Kawasan Konservasi Pelabuhan Tengkayu II Kota Tarakan Kalimantan Timur [Thesis]. Institut Pertanian Bogor. Bogor. [Indonesia]

Wihayanto, D. 2011. Kajian Pengelolaan Hutan Mangrove di Kawasan Perluasan Lahan Konservasi Desa Karang Rejo Kota Tarakan Kalimantan Timur, Jurnal Harpodon Borneo, Vol. 4, No. 2.

Yanur, Vita. 2017. Ekowisata Berbasis Masyarakat Wisata Alam Pantai Kubu", Jurnal Zira'ah, Vol, 42, No. 3

Yusuf, K. 2008. Sejarah dan pesona alam, kawasan Konservasi Mangrove Bekantan, Tarakan Kalimantan Timur. Tarakan: Pemerintah Daerah Kota Tarakan. 